\title{
КРИТИЧНА ОЦІНКА УКРАЇНСЬКИХ ТЕРМІНОЛОГІЧНИХ СЛОВНИКІВ
}

(Петрова Т. О. Українська термінографічна критика: становлення, розвиток та перспектива (на матеріалі критичної оцінки термінологічних словників): моногр. / переднє слово, наук. ред. проф. Т. А. Космеди. Харків: Майдан, 2021. 460 с.)

Термінографічна наука грунтується, по-перше, на строгій відповідності теорії, іiї законів і принципів, по-друге, на термінографічній практиці, що вимагає чималих зусиль від термінографів, по-третє, важлива й історія термінографії, що дає змогу простежити розвиток кожної національної термінографії. Але особливо потрібна й термінографічна критика, що як самостійний напрям лише окреслювалася впродовж тривалого часу, не маючи належного опису. Отже, рецензована монографія надзвичайно актуальна, оскільки вона заповнює лакуну українського мовознавства й стверджує наявність самостійного напряму критики термінографічних джерел. У цьому вбачаємо й важливість, і новизну цього дослідження.

Структура монографії Т. Петрової має традиційну організацію, але максимально подрібнена на розділи, підрозділи, параграфи й підпункти, що робить працю стрункою, чіткою, логічною. У ній усе концептуально пов'язане. Будова ії така: передмова наукового редактора професора, доктора філологічних наук Т. Космеди; список скорочень; кваліфіковано підготовлений вступ з усіма необхідними складниками, мотивованими жанром монографії; три розділи; висновки; списки використаної літератури, лексикографічних джерел та рецензій; додатки, де містяться аналізовані рецензії; покажчик термінів і покажчик імен.

У першому розділі «Історія становлення та розвитку української термінографічної критики» Т. Петрова встановлює зв'язки термінограбічної критики як самостійного напряму з термінознавством, термінографією, лінгвістикою тексту, джерелознавством, дискурслінгвістикою, лінгвоаксіологією, лінгвоекспертологією, науковою комунікацією тощо (п. 1.2.2). Мовознавиця висвітлює власну історію формування і поступу української критики термінографічних джерел як наукової інтегральної дисципліни, докладно характеризує іï 
методологійну основу та послідовно визначає ії базовий жанр - рецензію на термінологічний словник, удало інтерпретуючи іiі як «вторинний текст, у якому виклад інформації грунтується на результатах критичного оброблення та аналізування первинного тексту термінографічного видання» (п. 1.2.3).

Спираючись на теоретичні положення лінгвоаксіології, викладені в працях Т. Космеди, Ж. Краснобаєвої-Чорної, О. Халіман, А. Черненко, Т. Петрова доречно ставить в основу критичного діагностування термінографічних видань прийняті критерії оцінки, проєктуючи їх на термінографічну практику, ураховуючи кількість і якість інформації в словниках, установлення наукової цінності тощо. Простеживши панування оцінювального процесу у світовій науці, дослідниця грунтовно вивчає сучасні практики комплексного оцінювання спеціальних текстів, тобто лінгвістичного експертування й рецензування термінологічного словника. Здійснивши їх порівняльно-зіставний аналіз, авторка доводить, що ці практики, хоч і не тотожні, але рівнозначні, оскільки їм властиві оцінювальний, рекомендаційний характер досліджень, об’єктом їх аналізу є спеціальні тексти, застосовується поетапний алгоритм комплексного оцінювання якості праць тощо. Це стало підставою для спростування авторкою монографії стереотипного розуміння змісту терміна рецензування термінологічного словника. Дослідниця пропонує ввести до наукового обігу термін термінографічне експертування, а також, відповідно, термінографічна експертиза, що підвищить їх репутацію (п. 1.3). Погляд дослідниці справедливий, але наскільки популярними стануть пропоновані терміноодиниці, чи будуть їх широко використовувати? Як видається, ï необхідно кодифікувати, рекомендуючи до вживання. Це питання потребує обговорення.

Описана метамова (термінологічний апарат) української термінографічної критики, змодельоване іiі понятійне поле засвідчують активну взаємодію й перетинання з іншими термінополями суміжних наук, їх взаємозбагачення (п. 1.4), а також самостійність досліджуваного напряму.

У другому розділі «Система українських термінологічних словників: традиції та сучасність» Т. Петрова висвітлює трактування поняття термін в українській та зарубіжних (бельгійській, білоруській, британській, іспанській, польській, чеській тощо) термінологічних школах, узагальнює основні ознаки терміна. Учена доходить такого 
висновку: оскільки теоретичні ідеї зарубіжних термінологічних шкіл $€$ піонерними та панівними в Україні, відповідно, найважливіша проблема сучасного українського термінознавства - збереження національного характеру термінології за умов широких глобалізаційних процесів сучасності (п. 2.1). Із цим не можна не погодитися.

У цьому розділі логічно приділено увагу й кодифікаторам термінів - термінологічним словникам. Зокрема, уважно вивчивши наявні в термінологічній лексикографії класифікації спеціальних словників, науковиця визначила нагальну потребу створення “словника майбутнього” - нового типу термінографічного джерела (п. 2.3). Проаналізувавши традиційні й новаторські підходи в національній термінографії (п. 2.4), а також ураховуючи результати аналізу української природничої термінології як репрезентанта наукової картини світу, Т. Петрова запропонувала методологійні принципи укладання комбінованого галузевого словника нового типу, детально описуючи компоненти мега-, макро- й мікроструктури. Крім того, авторка вдало унаочнила розбіжності репрезентації у вузькогалузевому й галузевому словниках, що заслуговує особливої уваги, наприклад, параметрів 'дефініція', 'гіперо-гіпонімія'. Науковиця коротко описує параметр 'енциклопедична інформація', а варто було б, як видається, дещо розлогіше пояснити його суть і специфіку відображення в такому словнику. Беззаперечно, пропонована Т. Петровою модель галузевого комбінованого словника нового типу дасть змогу описати термінологію наукової галузі як систему знань (з ії підгалузями), відобразивши ії системні зв'язки (гіперо-гіпонімні, антонімні, синонімні) (п. 2.5). Ця робота, на нашу думку, є на часі.

Підкресливши актуалізацію аксіологічного принципу дослідження в термінографії, у третьому розділі «Рецензія як жанр лінгвістичної літератури: поняття, статус, типи, композиція, значення» Т. Петрова зосередила увагу на вивченні рецензї̈ на термінологічний словник, що є підсумком рецензування джерела, способом здійснення його критичного аналізу, виявлення ціннісних ознак і встановлення його наукової вартості. Крім того, дослідниця інтерпретує рецензію на термінологічний словник як репрезентант критичного субдискурсу (складник оцінювального дискурсу), а також як інтегральний жанр, пояснюючи, що він поєднує ознаки наукової комунікації, мовної критики й джерелознавства, що допускають експертизу й оцінку спеціальних видань (п. 3.1). 
Схвально й те, що авторка рецензованої праці вперше розробила типологію рецензій на термінологічні словники за різними параметрами, опрацювавши критичний дискурс рецензій, тобто опубліковані в українських лінгвістичних і галузевих наукових часописах (п. 3.2). Також дослідниця виділила критерії та алгоритм різнорівневого оцінювання термінографічного видання (п. 3.3). Важливо, що Т. Петровій удалося змоделювати інваріантну композицію рецензії на термінологічний словник і запропонувати рекомендації, що сприятимуть удосконаленню формально-змістової організації критичної інформації щодо термінографічного джерела (п. 3.4). Усебічно висвітлено й теоретико-практичне значення рецензій на українські фахові словники кінця XX ст. - початку XXI ст., зокрема, дослідниця наголошує, що теоретичне значення полягає в потенційній важливості використання результатів під час розроблення моделей сучасних словників і їx параметрів, а практичне - у можливості застосувати зауваження з прагматичною метою (п. 3.5).

Аналізуючи сучасні тенденції розвитку української термінографічної критики на слов'янському тлі (п. 3.7), на матеріалі рецензій кінця XX - початку XXI ст. української і російської критики словників учена довела, що відмінною тенденцією української критики є експертування термінів щодо відповідності українським мовним нормам, зокрема відстеження кальок з подальшим їх усуненням і пошуком нормативних варіантів (цей процес триває майже 100 років, що зумовлено результатом дії деукраїнізації), спостерігаються й тотожні тенденції, однакові принципи експертування фахових словників, якот: 1) усебічний аналіз галузевих словників щодо репрезентації їх параметрів з метою пошуку інваріантних способів опису термінології як системи в словнику нового типу; 2) визначення й посилення ролі та впливу термінологічних словників, підкреслення їх національно- й лінгвокультурологічного значення для розвитку національних наук. Такі підсумки заслуговують на увагу, оскільки їх урахування сприятиме поступу теоретичної і практичної термінографії.

Завершують монографію обгрунтовані висновки, що цілком вірогідні й фахово сформульовані. Списки використаної літератури, джерел та рецензій показують, що дослідниця добре обізнана з проблемою. Вражає широка апробація роботи, положення якої висвітлені у фундаментальних наукових часописах, а також опубліковані у виданнях, індексованих у Scopus. Додатки демонструють авторську лабораторію - зразки рецензій, що підлягали аналізу, експертуванню. 
Ретельно підібрані епіграфи до розділів, підрозділів монографії засвідчують ключову думку, яку авторка праці сповідує і втілює в тексті. Монографія Т. Петрової - важливе для української науки дослідження, що має новизну, широке теоретичне значення і практичне застосування, однозначно збагачує ії та проєктує її майбутнє.

Рецензована праця має зацікавити широке коло читачів: критиків фахових словників, термінологів, термінографів, лексикографів, фахівців з дискурслінгвістики, джерелознавства, лінгвоаксіології та ін., а також аспірантів, магістрів та студентів, що навчаються за філологічним профілем.

\section{ЛIТЕРАТУРА}

1. Петрова, Т. О. (2021). Українська термінографічна критика: становлення, розвиток та перспектива (на матеріалі критичної оцінки термінологічних словників). Харків: Майдан.

\section{REFERENCES}

1. Petrova, T. O. (2021). Ukrainska terminohrafichna krytyka: stanovlennia, rozvytok ta perspektyva (na materiali krytychnoi otsinky terminolohichnykh slovnykiv) [Ukrainian terminographic criticism: formation, development and perspective (on the material of critical evaluation of terminological dictionaries)]. Kharkiv: Maidan [in Ukrainian].

Халіман Оксана Володимирівна - доктор філологічних наук, доцент кафедри української мови, Харківський національний педагогічний університет імені Г. С. Сковороди; вул. Валентинівська, 2, Харків, 61168, Україна.

Tel.: +38-066-55-903-66

E-mail: khaliman_oksana@ukr.net https://orcid.org/0000-0001-6952-0627

Khaliman Oksana Volodymyrivna - Doctor of Philological Sciences, Associate Professor at the Department of Ukrainian Language, H. S. Skovoroda Kharkiv National Pedagogical University; 2 Valentynivska Str., Kharkiv, 61168, Ukraine.

\section{CITATION}

Надійшла до редакції 21 вересня 2021 року

ДСТУ 8302:2015: Халіман О. В. Критична оцінка українських термінологічних словників. Рец. на: Петрова Т. О. Українська термінографічна критика: становлення, розвиток та перспектива (на матеріалі критичної оцінки термінологічних словників): моногр. / переднє слово, наук. ред. проф. Т. А. Космеди. Харків: Майдан, 2021. 460 с. Лінгвістичні дослідження: зб. наук. пр. Харк. нац. пед. ун-ту імені Г. С. Сковороди. Харків, 2021. Вип. 55. С. 185-189. DOI: https://doi.org/10.34142/23127546.2021.55.18

AРA: Халіман, О. В. (2021). Критична оцінка українських термінологічних словників. Рец. на: Петрова Т. О. Українська термінографічна критика: становлення, розвиток та перспектива (на матеріалі критичної оцінки термінологічних словників): моногр. / переднє слово, наук. ред. проф. Т. А. Космеди. Харків: Майдан, 2021.460 с. Лінгвістичні дослідження, 55, 185-189. DOI: https://doi.org/10.34142/23127546.2021.55.18 